\title{
Tillage and nutrition for tannia [Xanthosoma sagittifolium (L.). Schott] raised as an intercrop in coconut gardens
}

Atul Jayapal and O. Kumari Swadija

Received : 16.04.2020; Revised : 08.05.2020; Accepted : 26.05 .2020

MEMBERS OF RESEARCH FORUM:

Corresponding author :

Atul Jayapal, Onattukara Regional

Agricultural Research Station

(K.A.U.), Kayamkulam (Kerala)

India

Email: atul.j@kau.in

Co-authors :

O. Kumari Swadija, Department of Agronomy, College of Agriculture

(K.A.U.), Thiruvananthapuram

(Kerala) India

Email: okswadija@yahoo.com

\begin{abstract}
Summary
A field investigation was conducted at College of Agriculture, Vellayani, Kerala during the year 2015-16 to study the role of tillage and nutrition in growth and yield of tannia raised as an intercrop in coconut gardens. The experiment was laid out in split plot design. The main plot treatments were $\left(1_{1}\right.$-conventional tillage followed by pit system, $1_{2}$-conventional tillage followed by mound system, $1_{3}$ - deep tillage followed by pit system and $1_{4}$ - deep tillage followed by mound system). The sub plot treatments were ( $\mathrm{s}_{1}-$ control, $\mathrm{s}_{2}-$ coir pith, $\mathrm{s}_{3}$ - rice husk) and ( $\mathrm{n}_{1}-$ integrated nutrient management (INM) and $\mathrm{n}_{2}$ - organic nutrition). Results of the experiment revealed that the growth and yield of tannia was improved by deep tillage with pit system of planting, application of coir pith as soil conditioner @ 500g plant ${ }^{-1}$ at the time of planting and providing organic nutrition (FYM @ $37.5 \mathrm{tha}^{-1}+$ wood ash @ $2 \mathrm{t} \mathrm{ha}^{-1}$ ) was highly beneficial.
\end{abstract}

Key words : Nutrition, Tannia, Tillage, Intercrop, Growth, Yield

How to cite this article : Jayapal, Atul and Swadija, O. Kumari (2020). Tillage and nutrition for tannia [Xanthosoma sagittifolium (L.). Schott] raised as an intercrop in coconut gardens. Asian J. Soil Sci., 15 (1) : 46-58 : DOI : 10.15740/HAS/AJSS/15.1/46-58. Copyright@ 2020: Hind Agri-Horticultural Society. 